\title{
IDENTIFICATION OF KOLB'S LEARNING STYLE IN SEVENTH GRADE STUDENTS AND THE EFFECT ON MISCONCEPTION IN SCIENCE LEARNING
}

\author{
Fitria Izza Tazkiah ${ }^{1)}$, Sri Mulyani' ${ }^{2)}$, Sentot Budi Rahardjo ${ }^{3)}$ \\ 1) Sebelas Maret University, Surakarta,, Indonesia \\ E-mail: fitriaizzatazkiah@student.uns.ac.id \\ ${ }^{2)}$ Sebelas Maret University, Surakarta, Indonesia \\ E-mail: srimulyaniuns@staff.uns.ac.id \\ ${ }^{3)}$ Sebelas Maret University, Surakarta, Indonesia \\ E-mail:sentotbr@staff.uns.ac.id
}

\begin{abstract}
The purpose of this study is to identify Kolb's learning style of seventh-grade students. Learning style is a combination of the way how the student absorbs then processes the information. Kolb's learning style, developed by David Kolb, combines students' learning tendency and produces four learning styles; they are diverger, assimilator, converger, and accommodator. Learning style is one of the factors can cause misconceptions. A misconception is a difference between a student's conceptions and the expert. Usually, the concepts are difficult to correct. This misconception will affect a student's achievement and disturb in understanding and developing a student's knowledge. The method applied in this study was a survey method with describtive qualitative technique. The data were collected using Kolb's Learning Style Inventory (KLSI) 3.1 version. The subjects were 78 students in three schools with high, medium, and low grades The results indicated that from 78 students, there were 40 divergers (51\%), 12 assimilators (15\%), ten convergers (13\%), and 16 accommodators (21\%). Each kind of learning style affects a student's misconception. This research benefits in identifying misconceptions probably faced by students in certain subjects of science learning.
\end{abstract}

Keywords: Accomodator, Assimilator, Converger, Diverger, Kolb's Learning Style, Misconception, Science Learning

\section{INTRODUCTION}

A misconception is a difference between a student's conception and the expert (Modell et al., 2005; Taber, 2010; Yamtinah et al., 2019). Usually, the concepts are challenging to correct (Berg, 1991). Brown states that misconception is a naïve (absurd) view and a different idea from accepted scientific understanding. Meanwhile, Fowler explains the details of misconception, namely: (1) an inaccurate understanding of the concept, (2) false using the concept, (3) false example classification, (4) confused different concept, and (5) incorrect the level of concept relationship (Suparno, 2013). If the misconceptions occur in students allowed to evolve more, the students will have difficulty understanding to the next concepts and level of education (Gagne et al., 1988). If the students have some misconception, it will assume that the concept is genuine, but the reality is false, affecting an expected learning process. Students will also get low achievement in process and product of learning (Ijirana \& Wahyuni, 2019). This is very important to know students' concepts understanding, so making learning goes smoothly and the same as the teacher's expected. The reason be strongly that all educators have responsibility to create meaningfull learning environment (Thambu et al., 2020). This study is expected for student's learning has a role in empowering human development, especially in science and education.

According to Suparno (2013), misconception type can be a form of the first concept, mistake, the false relationship between the concepts, intuitive ideas, and naive view. Several factors can cause misconceptions; they are from learners/students, teachers, books context, and teaching methods. One of the factors causing the internal students' misconception is a student's learning style (A'yun et al., 2017; Aryungga, 2014; Sen and Yilmaz, 2012;). According 
to DePorter \& Hernacky (2004), learning style is a combination and how a person absorbs and processes information. Kolb (Ignacio \& Reyes, 2017) explains that learning style helps individuals concentrate, process, internalize, and retain new and challenging information. Also, students use different approaches in observing and processing the information. The learning style is strongly believed can affect the student's concepts understanding because the students are studying by their each learning style so produce their best achievements (Alamdarloo et al., 2013; Bin Anualet al., 2018; Latisma, 2015) and affect the student's misconceptions. Besides, Kolb \& Kolb (2006) stated that it is important to know student's learning style to adapt teacher's style and pedagogy so increase student's learning.

Each student has a different learning style, which is formed by each learning tendency. According to David Kolb, there are four learning tendencies, and they are Concrete Experience (CE), Reflective Observation (RO), Abstract Conceptualization (AC), and Active Experimentation (AE) (Kolb, 1981). These four studying tendencies form 4 learning styles; they are diverger, assimilator, converger, and accommodator, called Kolb's learning style (Ghufron \& Risnawati, 2012). Ramlah (2014) and Azrai \& Sulistianingrum (2017) have proved that Kolb's learning style affects students' achievement. Furthermore, Latisma (2015) revealed that students with an assimilator learning style tend to understand. The student with a converger learning style tends to understand misconception, while the student with a diverger and accommodator learning style tend to have a misconception in Colloid materials. It can be used as an indicator that Kolb's learning style shows students' different conceptual understanding. The research becomes essential to know Kolb's learning style to create expected learning activities and minimize misconceptions in science learning.

\section{MEthodology}

This study was describtive qualitative research, which was used in the survey method. The subjects were VII B, VII C, and VII A in three schools with high, medium, and low grades. SMP A was a high grade, SMP B was a medium grade, and SMP C was a low-grade school. Instrument used in this study was KLSI (Kolb Learning Style Inventory) 3.1 version that develop by David Kolb (Kolb \& Kolb, 2005). This study's data were Kolb's learning style of student's score, which is includes nominal data. KLSI instrument used in this study contains 12 statements for each learning tendencies/quadrants (Concrete Experience (CE), Reflective Observation (RO), Abstract Conceptualization (AC), and Active Experimentation (AE)), so the sweeping statements are 48 items. The example of this istruments was shown by Table 1. The students must fill this instrument so it will describe their Kolb's learning style. The rules for scoring the instrument are shown by Table 2 . Next step, total each quadrants and plot the score to coordinates KLSI that shown in Fig. 1. It will result Kolb's learning that students have. Then, the result were combined and the percentage was calculated to determine the total of Kolb's learning style that student's have. Finnaly, the percentages of many kind of Kolb's learning style can be determined.

TABLE I

EXAMPLE OF KLSI (KOLB'S LEARNING STYLE INVENTORY)

\begin{tabular}{cccccc}
\hline No & Statements & \multicolumn{3}{c}{ Order of Statement } \\
\hline 1. & When I am Studying & $\ldots$ I am happy & $\ldots$ I am free & $\ldots$ I am logic & $\ldots$ I am careful \\
\hline
\end{tabular}

TABLE III

RULES FOR SCORING KLSI (KOLB'S LEARNING STYLE INVENTORY)

\begin{tabular}{ccc|}
\hline No & Score & Suitability with Student's Character \\
\hline 1. & 4 & Really appropriate \\
2. & 3 & Appropriate \\
3. & 2 & Quite appropriate \\
4. & 1 & Not appropriate \\
\hline
\end{tabular}

\section{RESULT AND DISCUSSION}

This research is conducted in three schools with high, medium, and low grades. The total of the subjects is 78 seventh-grade students. The instrument used is Kolb's Learning Style Inventory (KLSI) 3.1 version (Kolb \& Kolb, 2005). KLSI is an instrument to determine Kolb's learning style that was developed by David Kolb. According to Kolb, learning style is not a permanent psychological trait but a dynamic state that results from a synergistic transaction between people and their environment (Kolb \& Kolb, 2005). Kolb's learning style classifies the learning style based on learning tendency, which is forming four quadrants, namely through Concrete Experience (CE), Reflective Observation (RO), Abstract Conceptualization (AC), and Active Experimentation (AE). These quadrans form 4 Kolb's 
learning style types; they are diverger, assimilator, converger, and accommodator. Each learning style has different characters. Kolb's Learning Style Inventory (KLSI) consists of several statements that describe each Kolbs' learning style characters and four columns with score 1-4. The students must fill this instrument so it will describe their Kolb's learning style. The rules for scoring the instrument are shown by Table 2 .

KLSI instrument used in this study contains 12 statements for each learning tendencies/quadrants, so the sweeping statements are 48 items. This instrument is effectively used to determine Kolb's learning style of students who want to understand themselves better (Melinda,
2018). After students scoring the instrument, then the data is analyzed to determine Kolb's learning style for each student. Firstly, total each quadrant with the same statement's characters will get $\mathrm{CE}$ total, $\mathrm{RO}$ total, $\mathrm{AC}$ total, and $\mathrm{AE}$ total. Secondly, reduce the value of opposite quadrant, AC-CE, and AE-RO to determine Kolb's learning style. Suppose AC$\mathrm{CE}$ is positive $(+)$ and AE-RO is positive $(+)$. In that case, it includes diverger, if $\mathrm{AC}-\mathrm{CE}$ is negative (-) and $\mathrm{AE}-\mathrm{RO}$ is positive (+), it includes assimilator, if $\mathrm{AC}-\mathrm{CE}$ is negative (-) and $\mathrm{AE}-\mathrm{RO}$ is negative (-), it includes converger, and if $\mathrm{AC}-$ $\mathrm{CE}$ is positive $(+)$ and AE-RO is negative (-), it includes accommodator. The graph to determine Kolb's learning style is shown in Fig. 1.

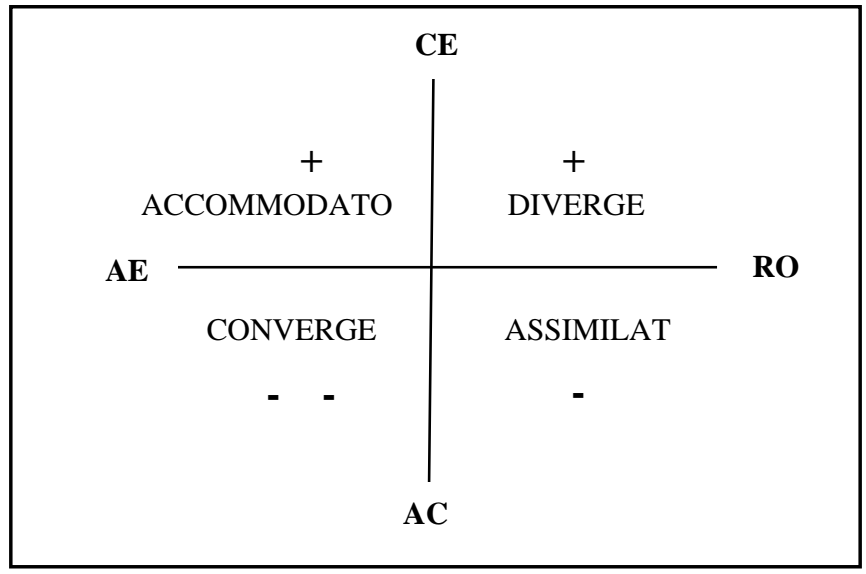

Fig. 1 Coordinates for Determining Kolb's Learning Style

Based on this research, the result of identification of Kolb's learning style in three schools as follows:

1) The result of Kolb's learning style identification in SMP A
The identification of Kolb's learning style was carried out in the VII B class. The result is shown in Table 3.

TABLE IIIII

IDENTIFICATION RESULT OF KOLB’S LEARNING STYLE IN VII B, SMP A

\begin{tabular}{lcc}
\hline \multicolumn{1}{c}{ Kolb's Learning Style } & Number of Students & Percentage (\%) \\
\hline Diverger & 20 & $63 \%$ \\
Assimilator & 5 & $16 \%$ \\
Converger & 2 & $6 \%$ \\
Accommodator & 5 & $16 \%$ \\
\hline
\end{tabular}

Table 3 shows 20 divergers, five assimilators, two convergers, and five accommodators. The most types of Kolb's learning style is diverger as many as 20 students $(63 \%)$

\section{2) The result of Kolb's learning style identification in SMP B}

The identification of Kolb's learning style was carried out in the VII C class. The result is shown in Table 4.

TABLE IV

IDENTIFICATION RESULT OF KOLB'S LEARNING STYLE IN VII C, SMP B

\begin{tabular}{lcc}
\hline \multicolumn{1}{c}{ Kolb's Learning Style } & Number of Students & Percentage (\%) \\
\hline Diverger & 12 & $44 \%$ \\
Assimilator & 5 & $19 \%$ \\
Converger & 3 & $11 \%$ \\
Accommodator & 7 & $26 \%$ \\
\hline
\end{tabular}


Based on Table 4, there are 12 divergers, five assimilators, three convergers, and seven accommodators. The most types of Kolb's learning style is diverger as many as 12 students $(44 \%)$.

\section{3) The result of Kolb's learning style identification in} SMP C

The identification of Kolb's learning style was carried out in the VII A class. The result is shown in Table 5.

TABLE V

IDENTIFICATION RESULT OF KOLB's LEARNING STYLE IN VII A, SMP C

\begin{tabular}{ccc}
\hline Kolb's Learning Style & Number of Students & Percentage (\%) \\
\hline Diverger & 8 & $42 \%$ \\
Assimilator & 2 & $11 \%$ \\
Converger & 5 & $26 \%$ \\
Accommodator & 4 & $21 \%$ \\
\hline
\end{tabular}

Based on Table 5, there are eight divergers, two assimilators, five convergers, and four accommodators. The most types of Kolb's learning style is diverger as many as eight students (42\%).
The total percentages of Kolb's Learning style are presented in Table 6, as follow:

TABLE VI

Total PERCENTAgES OF KolB'S LEARNING STYLE IDENTIFICATION RESUlt

\begin{tabular}{lcccc}
\hline \multirow{2}{*}{ School } & \multicolumn{4}{c}{ Kolb's Learning Style Model } \\
\cline { 2 - 5 } & Diverger & Assimilator & Converger & Accommodator \\
\hline SMP A & 20 & 5 & 2 & 5 \\
SMP B & 12 & 5 & 3 & 7 \\
SMP C & 8 & 2 & 5 & 4 \\
Total & 40 & 12 & 10 & 16 \\
Percentage & $\mathbf{5 1 \%}$ & $\mathbf{1 5 \%}$ & $\mathbf{1 3 \%}$ & $\mathbf{2 1 \%}$ \\
\hline
\end{tabular}

Based on Table 6 above, from 78 students in three schools, there are as many as 40 students (51\%) have a diverger learning style, 12 students $(15 \%)$ have an assimilator learning style, ten students (13\%) have a converger learning style, and 16 students $(21 \%)$ have an accommodator learning style. Diverger's learning style combines the Concrete Experience (CE) quadrant and Reflective Observation (RO) quadrant. CE quadrant reflects the feeling and RO quadrant reflects watching. Students with a diverger learning style are superior at seeing concrete situations from many different points of view. The approach used is "observing" not be "acting." Students will prefer to get assignments for outing many ideas (brainstorming), collect information, solve problems, and not be afraid to try somethings (Ranti et al., 2020). This Individual experience a situation and then later look at the situation through many perspectives, learning from each (Muro \& Terry, 2007). Besides, the power of this learning style lies in their imagines (Nasution, 2013). This learning style's weakness is quickly bored if the problem needs a lot of time to be understood, solved, or resolved (Gufron \& Risnawati, 2012). Next, the combination of Reflective Observation (RO) quadrant and Abstract Conceptualization (AC) are forming assimilator learning style. RO quadrant reflects watching and AC quadrant reflects thinking. Students with assimilator learning styles have advantages in understanding various information which is collected by various sources information. That information is viewed from various perspectives and summarized logically, concisely, and precisely (Ghufron \& Risnawati, 2012). Besides, the AC quadrant, which exists in students, has a good analysis of power. Assimilator learning style is more interested in abstract concepts than in applications (Indriana, 2011).

The converger learning style is a combination of Abstract Conceptualization (AC) and Active Experimentation (AE). $\mathrm{AC}$ quadrant reflects the thinking, and $\mathrm{AE}$ quadrant reflects doing. Students with a converger learning style have a character not to be emotional (Ghufron \& Risnawati, 2012). Besides that, from AE quadrant make the students more active during the process of learning. Students will excel in finding practical functions of various ideas and theories to solve problems and make the right decisions. Converger's learning style prefer applicative things and integrate observation into theory. Next, the combination of Active Experimentation (AE) and Concrete Experience (CE) are forming accommodator learning style. AE quadrant reflects doing, and CE quadrant reflects feeling. Students with an accommodator learning style are much to learn from real experience and face various problems. Besides, students will consider the human factor to get feedback or information (Gufron \& Risnawati, 2012). Students will choose how to exchange ideas with others (teachers or friends) to solve the problems. It is in line with Ranti (2020), which states that accommodators like taking action in involving themselves in a situation just the challenge, relying on information from others, or choose to exchange thoughts with other students. In this fact, the individuals have power to do plans and task in new activities (Turesky \& Gallagher, 2011).

The study of Kolb's learning style also has been done by Othman (2012). His research shows that the most types of 
learning style haven by students is converger learning style $(31,66 \%)$, then accommodator $(26,67 \%)$, next diverger $(21,67 \%)$, and at last assimilator $(20 \%)$. Othman's research quitely different from this study, where the most types of Kolb's learning style are diverger learning style, then accommodator, next assimilator, and at last converger learning style. This research is supported by Marningsih's (2012) study that concludes the most majority of Kolb's learning styles are diverger and accommodator. Kolb's learning styles possessed by students have various characters. Research by Ramlah (2014) and Azrai \& Sulistianingrum (2017) have proved that Kolb's learning style affects academic students' achievement. Several studies mention that Kolb's learning style can also affect the students' conceptual understanding and misconceptions in science learning. Students with assimilator learning styles tend to be the partial understanding category; converger students tend to be the partial understanding category with misconceptions. In contrast, students with diverger and accommodator learning styles tend to have misconceptions about Colloid material (Latisma, 2015). It is also confirmed from research doing by Sen \& Yilmaz (2012) states that students with an assimilator learning style have a slight level of misconceptions compared with converger learning style on Amalgamation and Dissolution materials. Students with assimilator learning style have higher spatial ability than the other learning style type on Hydrocarbon materials (Melinda $\&$ Wisudawati, (2018)). Someone with a converger learning style has higher problem achievement than an assimilator learning style on the Chemistry subject (Ozgur, Temel, and Yilmaz, (2012)). Students with different Kolb's learning styles can lead to having different misconceptions. This research benefits in identifying misconceptions based on Kolb's learning styles in science learning.

\section{CONCLUSIONS}

From 78 students, there were 40 divergers (51\%), 12 assimilators (15\%), ten convergers (13\%), and 16 accommodators (21\%). Each kind of student's learning style affects their misconceptions. This research benefits in identifying misconceptions based on Kolb's learning styles in science learning.

\section{ACKNOWLEDGMENT}

The authors would like to thank supervisor and the school (headmaster and science teachers) who have permitted them to practice this research and help everything very well.

\section{REFERENCES}

A’yun, K., Suyono, Poedjiastoeti, S., \& Bin-Tahir, S. Z. (2017). Reduction of cognitive conflict and learning style impact towards student-teacher's misconception load. AIP Conference Proceedings, 1868 (September).
Alamdarloo, G. H., Moradi, S., \& Dehshiri, G. R. (2013). The Relationship between Students' Conceptions of Learning and Their Academic Achievement. Psychology, 04(01), 44-49. https://doi.org/10.4236/psych.2013.41006

Aryungga, S., D., E. \& Suyono. (2014) Identifikasi Gaya Belajar Siswa yang Mengalami Miskonsepsi Resisten pada Konsep Kimia. Journal of Chemical Education, 3 (01), 127-134.

Azrai, E. P., Ernawati, E., \& Sulistianingrum, G. (2017). Pengaruh Gaya Belajar David Kolb (Diverger, Assimilator, Converger, Accommodator) terhadap Hasil Belajar Siswa pada Materi Pencemaran Lingkungan. Biosfer: Jurnal Pendidikan Biologi, 10(1), 9-16. https://doi.org/10.21009/biosferjpb.10$\underline{1.2}$

Berg, E. Van Den. (1991). Miskonsepsi Fisika dan Remediasi. Universitas Kristen Satya Wacana.

Bin Annual, N., Faizal bin Samat, M., Himmah bte Abd. Karim, Z., \& Hashim, N. (2018). Learning Styles and Academic Achievement Among University Students. June 2018, 520-526. https://doi.org/10.5220/0006888905200526

DePoter, B., \& Hernacki, M. (2004). Quantum Learning: Membiasakan Belajar Nayaman dan Menyenangkan. Bandung: Kaifa.

Gagne, R. M., Briggs, L. G., Briggs, L. G., \& Wager, W. W. (1988). Principle of Instructional Design. Florida: Holt, Rinehart, and Winston, Inc.

Ghufron, M. N., \& Risnawati, R. S. (2012). Gaya Belajar Kajian Teoritik. Yogyakarta: Pustaka Belajar.

Ignacio Jr., A. G., \& Reyes, J. D. (2017). Exploring Mathematics Achievement Goals Using Kolb's Learning Style Model. Asia Pacific Journal of Multidisciplinary Research, 5(1.2), 19-24.

Ijirana, I., \& Wahyuni, S. (2019). The Chemistry Competency Achievement of SMA Negeri 7 Palu Students Using Predict, Observe, and Explain (POE) Learning Model. IJOLAE: Indonesian Journal on Learning and Advanced Education, 1(1), 9-13. https://doi.org/10.23917/ijolae.v1i1.7474

Indriana, D. (2011). Mengenal Ragam Gaya Pembelajaran Efektif. Yogyakarta: Diva Press.

Kolb, A. Y., Based, E., Systems, L., \& Kolb, D. A. (2015). The Kolb Learning Style Inventory - Version 3 . 1 2005 Technical Specifi cations. January 2005.

Kolb, A. Y., \& Kolb, D. A. (2006). Learning styles and learning spaces: A review of the multidisciplinary application of experiential learning theory in higher education. In R. R. Sims, \& S. J. Sims (Eds.), Learning styles and learning: A key to meeting the accountability demands in education (pp. 45-92). New York: Nova Science Publishers.

Kolb, A. Y., \& Kolb, D. A. (2005). Learning styles and learning spaces: Enhancing experiential learning in higher education. Academy of Management Learning and Education, 4(2), 193-212. https://doi.org/10.5465/AMLE.2005.17268566 
Kolb, D. (1981). Learning styles and disciplinary differences. January 1981, 232-255.

Latisma, D., Rahmi, L. F., \& Indang, D. (2015). Analisis Kecenderungan Pemahaman Konsep Siswa Ditinjau Dari Gaya Belajar Pada Materi Sistem Koloid Di SMA Kerinci. Prosiding SEMIRATA 2015 Bidang MIPA BKS-PTN Barat Universitas Tanjungpura, Pontianak, 523-532.

Marningsih, T. (2012). Kolb Learning Styles Relationship with Student's Achievement. Thesis. Retrieved December 5, 2020, from http://repository.uksw.edu/bitstream

Melinda, G. M. (2018). Identifikasi Gaya Belajar Model Kolb Terhadap Peserta Didik Man II Yogyakarta. Jurnal Pendidikan Sains (Jps), 6(1), 47. https://doi.org/10.26714/jps.6.1.2018.47-55

Modell, H., Michael, J., \& Wenderoth, M. (2005). Helping the Learner to Learn: The Role of Uncovering Misconceptions. The American Biology Teacher, 67(1), 20-26. doi:10.2307/4451776

Muro, P.D., \& Terry, M. (2007). A Matter of Style: Applying Kolb's Learning Style Model to College Mathematics Teaching Practices. Journal of College Reading and Learning. 38. 53-60. 10.1080/10790195.2007.10850204.

Nasution, S. (2013). Berbagai Pendekatan dalam Proses Belajar Mengajar. Jakarta: Bumi Aksara.

Othman, N., \& Othman, S. R. (2012). Gaya Pembelajaran Kolb dalam Mata Pelajaran Biologi. Jurnal Teknologi, January 2012. https://doi.org/10.11113/jt.v40.429

Ozgur, S. D., Temel, S., \& Yilmaz, A. (2012). The Effect of Learning Styles of Preservice Chemistry Teachers on Their Perceptions of Problem Solving Skills and Problem Solving Achievements. Procedia - Social and Behavioral Sciences, 46, 1450-1454. https://doi.org/10.1016/j.sbspro.2012.05.319
Ramlah, Firmansyah, D., \& Zubair, H. (2014). Pengaruh Gaya Belajar Dan Keaktifan Siswa Terhadap Prestasi Belajar Matematika. Jurnal Ilmiah Solusi, 1(3), 68-75.

Ranti, Darsikin, \& Saehana, S. (2020). Analisis Gaya Belajar Siswa Berprestasi Mata Pelajaran Fisika di Kelas IX MIA SMA Al-Azhar Palu. Jurnal Kreatif Online, 8(1), 94-101.

Sen, S., \& Yilmaz, A. (2012). The Effect of Learning Styles on Student's Misconceptions and Selfefficacy for Learning and Performance. Procedia - Social and Behavioral Sciences, 46(April 2016), 1482-1486. https://doi.org/10.1016/j.sbspro.2012.05.325

Suparno, P. (2013). Miskonsepsi dan Perubahan Konsep dalam Pendidikan Fisika. Jakarta: Grasindo.

Taber, K. (2010). Challenging Misconceptions in the Chemistry Classroom: Resources to Support Teachers. Educació Química, O(4), 13-20-20. https://doi.org/10.2436/eduq.v0i4.809

Thambu, N., Prayitno, H. J., \& Zakaria, G. A. N. (2020) Incorporating Active Learning into Moral Education to Develop Multiple Intelligences: A Qualitative Approach. Indonesian Journal on Learning and Advanced Education (IJOLAE), 3(1), 17-29. https://doi.org/10.23917/ijolae.v3i1.10064

Turesky, E. F., \& Gallagher, D. (2011). Know thyself: Coaching for leadership using Kolb's Experiential Learning Theory. The Coaching Psychologist, 7(1), 5-14.

Yamtinah, S., Indriyanti, N. Y., Saputro, S., Mulyani, S., Ulfa, M., Mahardiani, L., Satriana, T., \& Shidiq, A. S. (2019). The identification and analysis of students' misconception in chemical equilibrium using computerized two-tier multiple-choice instrument. Journal of Physics: Conference Series, 1157(4). https://doi.org/10.1088/1742$6596 / 1157 / 4 / 042015$ 